word may be said. I think that I am not in error in saying that the minds of most persons are imbued, more or less deeply, with the idea that nature is ultimately very simple; that could we but grasp the great laws of nature we should find them extremely simple, although the results of their actions are so wonderfully complex. This belief appears to be deep-rooted in most minds, yet if we are to study nature aright we must, I am persuaded, set it aside. We must be content to take nature as she is, i.e., we must do our best to amass facts, and from these we must draw the conclusions warranted by the facts. Now as our knowledge of nature extends do we find that she becones to us more and more simple? Yes, and No. It has been now and again given to a gifted few to pierce through the maze of tangled facts and to espy the great principle which binds them into an harmonious whole. But even in the case of these great generalisations, exact experiment and observation frequently show that little details have been overlookedthat the great simple law is too simple-that there are discrepancies, very small, it is true, but still there they are, demanding an explanation, telling us that our law does not express the whole of Nature's facts. Nature appears to be truly infinite; and it is well to remember that, we can never get sensibly nearer a knowledge of an infinity.

This idea of the simplicity of nature is very apt to lead us to adopt the hypothesis of the non-elementary nature of the elements without sufficient evidence. The idea that all the elements are really compounds of one primary form of matter is a most fascinating idea, it seems to be so much in keeping with the simplicity of nature; it is so symmetrical, it surely must be true. This is just how the old alchemists reasoned; we must absolutely forbid these it priori conclusions to infuence us as students of nature. The hypothesis of the compound nature of the elements, of the existence of but one, or even of a few primary forms of nature, fits in with the nebular hypothesis of the formation of the worlds, but have we facts to support it? If one can only come back to facts we need not fear to start what may appear to be wild and romantic theories.

The outcome of the whole matter is this:-we want more knowledge, our facts are few and vague; there is room for almost unlimited work. Ask Nature; trust her: be sceptical of your own interpretations of her answers.

M. M. PATTISON MUIR

THE LATE SIR RICHARD GRIFFITH, BART.

$W E$ have just laid to rest all that is mortal of the "Father of Irish Geology" in Mount Jerome public men in Ireland have done so much for the material advancement of their country. If "the age makes the man" the late Sir Richard Griffith was the man whom the age called forth to indicate the road to material improvement at a time when roads, railroads, drainage works, and similar agents were urgently required in this country. Griffith's geological knowledge was the basis of his power; and while few understood, or cared to understand, the principles by which his judgment was guided, Government and the public were always ready to put faith in their application. Amongst the useful works carried out under his direction were the roads which he constructed or improved in the counties of Cork, Kerry, and Limerick, during the time when the Marquis Wellesley was Lord-Lieutenant. Some of these roads are striking examples of engineering skill. I have recently travelled on one of them, namely, that which crosses the wild and rocky range between Kenmare and Glengarriff. Before this road was made the country was inaccessible and the haunt of Whiteboys; now no district in the British Isles is safer for the traveller, and, I may add, more full of bold and beautiful scenery. With reference to Griffith's services to the cause of Irish geology, it is unnecessary for me to say a word here, except in so far as regards the public department with which I have the honour to be connected. It is to this subject that I wish especially to direct the attention of the readers of NATURE, as I am anxious to pay a tribute to the remarkable acumen which Griffith exhibited in determining the age of the various formations which are to be found in this country, as exemplified in at least one special instance.

It is well known that there is one point in the geological structure of the south-west of Ireland on which there has been a difference of opinion between the Government geological surveyors and Sir R. Griffith; I refer to the age of that great group of rocks which occupies the mountainous districts of the Dingle promontory, and those of Killarney, the Reeks, and Glengarriff. These were called by the late Prof. Jukes "The Dingle Beds," and they consist of a series of purple slates traversed by cleavage planes and massive green grits, and thrown into numerous grand flexures. They are of great but unknown thickness, as in the Dingle promontory they are overlaid unconformably by the beds of the Old Red Sandstone. In the Dingle promontory these beds are seen in. contact with fossiliferous beds of recognised Upper Silurian age, and the whole series had been referred by Griffith to the "Silurian" formation, as may be seen by reference to his geological map of Ireland (edit. 1855). In a similar manner the mountainous regions abovenamed, and lying to the south of Dingle Bay, were mapped and coloured as "Silurian," and were separated off from the Old Red Sandstone throughout the counties. of Cork, Kerry, and Waterford.

The views thus held and published by Griffith with regard to the geological age of the rocks forming the south-western highlands were not upheld by the officers of the Geological Survey, who, we may be sure, spared no pains to come to some clear decision on the question. On the maps of the Survey the mountains of Kerry and Cork are coloured "Old Red Sandstone," and "the Dingle Beds," with a distinct colouring, are placed in a position intermediate between the Old Red Sandstone and that of the Upper Silurian. Prof. Jukes, in the "Explanations" to accompany the maps of the Survey, has fully entered into the reasons which induced him and his able colleagues to arrive at this decision. Certain apparent obscurities in the sections of the Dingle district and those of the neighbouring regions prevented them accepting Griffiths' views, and the whole matter was left an open question, subject to further investigation.

Under these circumstances- the time being favourable -I received the sanction of the Director-General to make a preliminary examination of the sections at Dingle and in the districts of Killarney, Kenmare, and Glengariff - with a view (if possible) of coming to some decision on a question which has been confessedly left in an unsatisfactory position. In this tour I was accompanied by Mr. J. O' Kelly and Mr. A. McHenry, officers of the Survey-and we have returned from it fully satisfied in our own minds of the correctness of Sir R. Griffith's views regarding the age of the beds of the Dingle, Killarney, and Glengarriff Ranges. To our minds the evidence is clear and satisfactory that these beds are really of Upper Silurian age, as maintained by Griffith. Into this evidence I cannot enter here, but hope to do so at some length in another place. It was with great gratification that some days since $I$ addressed a letter from Eccles' Hotel, Glengarriff, to Sir R. Griffith, announcing the result of our investigations. I little knew that at that noment the spirit of our venerable friend had passed away! Few men were less dogmatic in maintaining their conclusions than Griffith. If others differed from him he remitted the matter to the arbitrament of time, satisfied that if he was in the rigbt time would show it. In this case it is only justice to his 
memory to bear testimony to the soundness of his judgment. EDWARD HULL Geological Survey Office, Dublin, September 27

ROBERT HARKNESS, F.R.S.

$A$ NOTHER of the captains in the phalanx of British geologists has dropped from the ranks. Robert Harkness died suddenly in Dublin on Saturday last. $\mathrm{He}$ had been ailing for some time, and the disease from which he suffered-an affection of the heart-had gained ground so much this year that he lately felt himself compelled to resign the chair of geology at Cork. It was the expectation of his friends that, released from duties which he had so long conscientiously performed, he might yet enjoy some years of comparative health in the quiet retirement of his Cumberland home, to which he used to return with such pleasure every summer. But this was not to be. He has fallen just as he had himself brought the public labours of his life to a close.

It is now some five-and-thirty years since the name of this able geologist first appeared as a writer on his favourite science. During this long period he had explored, on foot; the geology of large districts in the north of England, in Scotland, and in various parts of Ireland. The reports of the British Association and the Quarterly Journal of the Geological Society bear witness to his industry and to the painstaking minuteness of his method of investigation. To him we owe our earliest exact information regarding the correlatives of the reptiliferous sandstones of Dumfriesshire and Cumberland. It was his patient labours continued year after year over ground most difficult to unravel, that led the way to the working out of the structure of the silurian uplands of the south of Scotland. To his research, too, is due the identification of the metamorphic rocks of the north-west of Ireland with those of the west of Scotland. To the elucidation of every one of the palæozoic systems of deposits he contributed something of value.

But important as was his scientific work, it had not a wider and more hearty recognition among his brother seologists than his own admirable qualities of head and heart. Who that has been privileged with his friendship will not cherish the memory of his earnestness over even the driest of details, his quiet enthusiasm, his generous admiration for the work of others, his unfailing cheerfulness? Who will forget that beaming ruddy face, never absent from the platform of Section $\mathrm{C}$ at the British Association meetings, always ready to rise among the speakers there and to reappear at the festive gatherings in the evening? There have been men who have graven their names more deeply on the registers of scientific thought and progress, but there have been few whose sunny nature has more endeared them in the recollection of their friends than Robert Harkness.

A. $\mathrm{G}$.

\section{MANGANESE NODULES IN LOCH FYNE}

$0 \mathrm{~N}$ September $2 \mathrm{r}$, this year, $\mathrm{I}$ anchored the steam yacht Mallard near the mouth of Loch Fyne, in ro4 fathoms, for the purpose of making physical and chemical observations on the water of this, the deepest part of the Firth of Clyde. When the anchor was got up a large mass of clay and shells was found sticking to one of the flukes. It was gently dried, and on examining it I observed a number of nodular concretions, which, on being freed from the surrounding clay, presented a finely mammillated black surface, were easily cut with a knife, giving a brownish-black powder, which liberated chlorine from strong hydrochloric acid, and possessed all the properties of peroxide of manganese; in short, they were identical with the manganese nodules which we found in the Challenger to form so important a constituent of the sea-bottom in the greatest depths.
One half of the dried mud was carefully broken up and searched through, the nodules being collected by themselves and also the shells. It was thus separated into three portions, which were weighed, with the following results :-

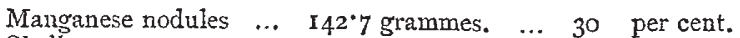

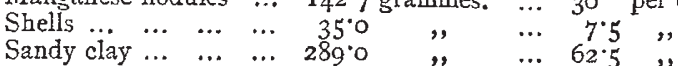

$$
\begin{aligned}
& \text { Total ... ... }
\end{aligned}
$$

The manganese nodules, therefore, made up thirty per cent. of the weight of the mud. Compared with those frequently met with on board the Challenger, the nodules were small. In the sample examined there were eighty-three nodules weighing $142^{\circ} 7$ grammes, hence the average weight was $I^{\prime} 7$ grammes. Their volume was found to be $58 \mathrm{c.c}$., so that the average volume was 0.7 c.c., and the specific gravity 246 . Their form was roughly spherical, the largest, which was somewhat elongated, measured I $3 \times 9 \times 6$ millimetres, the average diameter of them all being I 4 . 4 millimetres.

Of the eighty-three nodules so obtained I have split twenty-two. When subjected to this treatment they are found to differ in constitution from the majority of those obtained on board the Challenger. Although they had not been exposed to any heat they were hard and sandy to the knife, and when treated with strong hydrochloric acid, they left a large amount of mineral (chiefly quartz) sand. This difference, however, is explained by the different kind of bottom from which they were obtained. In dissolving up nodules which had come from "red clay" in 2,500 or 3,000 fathoms I always found the same mineral sand left as on treating the clay in the same way. But the amount of sand was always quite insignificant, as compared with the clay; hence the nodules were easily cut with the knife. They, however, got harder on keeping. In Loch Fyne the bulk of the mud consists of quartz sand, giving the nodules the appearance of sandstone, whose binding material is made up to a great extent of peroxide of manganese, and hence the gritty feeling to the edge of the knife.

Where a hard nucleus has been found it has always been a piece of rock from the neighbouring shore, but in most instances (in sixteen out of twenty-two examined) the ordinary arrangement has been reversed, the nodule consisting of a soft rich nucleus of peroxide of manganese, surrounded by a black sandy rind, the whole enveloped in the characteristically mammillated black skin.

I hope very shortly to be able to report more fully on them; in the meantime, I have only been able to verify their nature by finding abundance of a higher oxide of manganese, easily recognisable quantities of cobalt, and the presence of water, which, on being expelled by heat, has an alkaline reaction and an empyreumatic odour, properties in which they agree with those which I had occasion to test on board the Challenger.

Their position in the mud, with dead shells above, below, and on all sides of them, will, when carefully studied, no doubt throw much light on their age and method of formation. I have observed two nodules firmly attached to the interior of shells, one having evidently been directed in its growth by the shape of the shell.

In endeavouring to procure a further supply $I$ dropped anchor in about the same depth, but about a hundred yards further down the loch, and I obtained aboat the same amount of mud, but it contained very much more shell and no nodules. Also in Kilbrennan Sound, between Arran and Cantyre, in a depth of eighty-five fathoms, there was much shell and pebble, but no nodules. So far, therefore, this occurrence appears to be very local.

J. Y. BUCHANAN 